\title{
Cosmogenic nuclide dating of cave sediments in the Eastern Alps and implications for erosion rates
}

\author{
Philipp Häuselmann (D ${ }^{1,2^{*}}$, Lukas Plan (D) ${ }^{3}$, Peter Pointner ${ }^{4}$, and Markus Fiebig (D) ${ }^{2}$ \\ ${ }^{1}$ Swiss Institute for Speleology and Karst Studies SISKA, Serre 68, 2301 La Chaux-de-Fonds, Switzerland \\ ${ }^{2}$ Institute for Applied Geology, University of Life Sciences BOKU, Peter Jordan Strasse 82, 1190 Wien, Austria \\ ${ }^{3}$ Karst and Cave Group, Natural History Museum Vienna, Museumsplatz 1/10 A-1070 Wien, Austria \\ ${ }^{4}$ Society of Speleology of Salzburg, Schloss Hellbrunn - Objekt 9, A-5020 Salzburg, Austria
}

\begin{abstract}
Karstic caves are created by water eroding and corroding rocks that can be dissolved. Since both the spring areas of caves (normally at the valley bottom) as well as the recharge is controlled by superficial processes, the morphology of the cave bears strong links to these influences. Lowering of local base levels promotes the development of horizontal phreatic cave passages at progressively lower elevations, resulting in the formation of multi-level karst systems. Upon the next lowering of base level, these upper systems become fossilized, and sediment trapped within them may remain preserved for millions of years. Dating these sediments gives clues regarding the time when the passages were last active, and thus may yield age information for old valley floors. The present paper presents cosmogenic nuclide datings of twelve samples from eight caves in the central part of the Northern Calcareous Alps of Austria. Besides three samples that gave no results, most of the obtained ages are at the Mio-Pliocene boundary or within the Pliocene, as was expected before sampling. No multilevel caves could be sampled at different elevations, thus, the obtained valley deepening rates are averages between the age of sediment deposition and the present-day valley floor. However, the valley deepening rates of 0.12 to $0.21 \mathrm{~km} / \mathrm{Ma}$ are in accordance to previous findings and corroborate a comparatively slow evolution of base level lowering in the Eastern Alps compared to the fast (Late Quaternary) evolution in the Central and Western Alps.
\end{abstract}

Keywords: $\quad$ Eastern Alps, cosmogenic dating, caves, valley incision, landscape evolution

Received 29 December 2019; Revised 29 May 2020; Accepted 29 May 2020

Citation: Häuselmann P., Plan L., Pointner P. and Fiebig M., 2020. Cosmogenic nuclide dating of cave sediments in the Eastern Alps and implications for erosion rates. International Journal of Speleology, 49 (2), 107-118. Tampa, FL (USA) ISSN 0392-6672 https://doi.org/10.5038/1827-806X.49.2.2303

\section{INTRODUCTION}

Speleogenesis and surface landscape development in mountain ranges is the result of interplay between tectonic uplift and climate-controlled erosion. Quantifying the rate at which landscape-modelling processes acted in the past requires the accurate dating of geomorphic markers. In rapidly eroding landscapes - especially if they have been glaciated - these markers are often removed by subsequent erosion, so that records are missing for the last few million years. Landscape evolution in the European Alps has been a major topic of research for Earth scientists during the past decades (Kuhlemann, 2000; Frisch et al., 2008). The effects of landscape modeling processes are quantified using estimated sediment budgets, fission track analysis (Cederbohm et al., 2004), and the dating of geomorphic markers like fluvial terraces, glacial moraines, and erosion surfaces.
Caves can provide additional clues for understanding landscape development. In karst regions, gradual lowering of valley floors and local base levels by river incision or glacial erosion promotes the development of horizontal phreatic cave passages at progressively lower elevations, resulting in the formation of multilevel karst systems (Audra et al., 2006; Columbu et al., 2015). Sediments that have been washed into these caves may be preserved from on-going erosion.

Dating sediments from various cave levels can provide information about the pace of landscape development, and in particular, valley incision rates, provided that the sediments are in a primary position and can be related to the development of the cave (Granger \& Muzikar, 2001). The minimum age of a cave can be determined by dating the sediments it contains, which are younger than the cave itself. The most widely used techniques are U-Th disequilibrium dating, paleomagnetic analysis, and burial age dating 
on cosmogenic nuclides. Applications in the field of cave paleontology is also possible, particularly for dating sites of Middle Pleistocene to Pliocene age. U-Th dating can seriously underestimate the age of the caves, because speleothems can grow a long time after the cave formation, and foremost, the method is limited to ca. 0.5-0.7 Ma (Stock et al., 2005a). Paleomagnetic dating requires correlation with the global reversal chronology (e.g., Häuselmann et al., 2015), but in caves, a continuous stratigraphy is rarely available.

The burial age method involves the measurement of two isotopes $\left({ }^{26} \mathrm{Al}\right.$ and $\left.{ }^{10} \mathrm{Be}\right)$ that are produced by cosmic radiation in quartz near the surface prior to burial. ${ }^{26} \mathrm{Al}$ and ${ }^{10} \mathrm{Be}$ accumulate at a ratio of about 6.8:1 (Balco et al., 2013) in quartz grains with a rate of a few atoms per gram of quartz per year. Sufficiently deep burial (more than $10 \mathrm{~m}$ ) of such quartz-rich sediment in a cave assures shielding from further cosmic rays. After burial the ${ }^{26} \mathrm{Al}$ and ${ }^{10} \mathrm{Be}$ concentrations in the sample are only affected by their relative decay resulting in a decrease in the ${ }^{26} \mathrm{Al} /{ }^{10} \mathrm{Be}$ ratio. This ratio measured can be used to derive a burial age (Gosse \& Phillips, 2001; Granger \& Muzikar, 2001). The current upper limit for measurement of the ${ }^{26} \mathrm{Al}$ and ${ }^{10} \mathrm{Be}$ isotope pair is around $5 \mathrm{Ma}$. A prerequisite of the burial dating technique is that samples have been exposed long enough to cosmic rays and accumulated sufficient cosmogenic nuclides prior to burial. Unfortunately this cannot be determined a priori in the field. The burial dating method was already successfully applied in the Western Alps (Siebenhengste, west-central Switzerland), where the incision rate of the valleys was estimated to have been $0.14 \mathrm{~mm} / \mathrm{a}$ during the Pliocene and $1.1 \mathrm{~mm} /$ a during the Middle (and Upper) Pleistocene (Häuselmann et al., 2007).

With the exception of a study on non-glaciated parts of the Eastern Alps (Wagner et al., 2010), there were no burial age dating results so far in the Eastern Alps. Here we present age dating for a range of caves in the Northern Calcareous Alps, a region which was glaciated during the Pleistocene and from which no hard age dating regarding the time of cave formation has been given so far.

\section{PREVIOUS STUDIES ON LANDSCAPE EVOLUTION IN THE EASTERN ALPS}

Data for the Eastern Alps (Kuhlemann et al., 2001) indicate a slow erosion rate in the Miocene $(0.2 \mathrm{~mm})$, followed by an increase in the Pliocene and Pleistocene. Szekely (2003) used digital elevation models to quantify uplift and erosion rates. He concluded that uplift was in the order of $0.13 \mathrm{~mm} / \mathrm{a}$ in the Pliocene and $0.28 \mathrm{~mm} / \mathrm{a}$ in the Quaternary, thus much slower than the previous studies. Fission track data from the Central Alps (Bernet et al., 2001) assume a steadystate exhumation of 0.4 to $0.7 \mathrm{~mm} / \mathrm{a}$ for the last $15 \mathrm{Ma}$.

The Northern Calcareous Alps (NCA) provide an ideal application for landscape evolution studies based on cave sediments because the caves show a clear vertical distribution as they form levels at certain altitudes. Attempts have been made to empirically link this distribution pattern to the geomorphic history of the Alps, but numerical ages for the caves could not yet be determined. Estimations based on data other than caves indicate slow valley incision rates during the Miocene and an increase during the Pliocene and Pleistocene (Kuhlemann et al., 2001).

While the western part of the NCA lack plateau morphologies, the eastern part of the NCA is characterized by huge (up to $1,000 \mathrm{~km}^{2}$ ) karst plateau systems developed at elevations between roughly 1,600-2,500 $\mathrm{m}$ a.s.1. (Frisch et al., 2001). The NCA consist of a sedimentary succession ranging from Permo-Triassic to Eocene times. The plateaus developed mainly on an often more than $2 \mathrm{~km}$ thick sequence of Triassic carbonates dominated by the Upper Triassic Dachstein limestone.

During the past century, two competing theories emerged on the genesis of these plateaus: (1) the idea of the Rax Landscape, a one-phased uniform peneplained paleosurface which was later dismembered and differentially uplifted (Lichtenecker, 1924, 1926) and (2) a polycyclic piedmont formation (Augenstein Landscape) with several periods of tectonic quiescence in which planation surfaces of limited extent formed, interrupted by repeated phases of uplift (WinklerHermaden, 1957; Langenscheidt, 1986).

The controversy was lifted by Frisch et al. (2001, 2002) who summarized the evolution as follows: the karst plateaus are relicts of the so-called Dachstein Paleosurface that formed in late Eocene to early Oligocene times as karst peneplains. In the Oligocene, the paleosurface subsided and was sealed by the Augenstein Formation, a terrestrial sequence of conglomerates and sandstones. The material of the Augenstein Formation is rich in polycrystalline quartzite and consist of greywacke slate, phyllite, gneiss, and carbonates. The source area of the sediments was south of the NCA in the Paleozoic Greywacke Zone which is only a narrow strip today but covered significant parts of the Austro-Alpine Crystalline during the Paleogene. Deposition of the Augensteine ended in the late Early Miocene, when E-W-trending valleys formed in the south of the NCA, cutting off sediment input from the source area (Frisch et al., 1998). Following the uplift of the NCA, the bulk of the Augenstein Formation was eroded and re-deposited in the Molasse basin north of the Alps. From Upper Miocene times ( 10 Ma), the denuded paleosurface experienced uplift in several pulses, but as karstification of the thick limestones allowed the development of underground drainage, no significant surface erosion took place and the landscape was preserved (Frisch et al., 2001).

The karst massifs of the central and eastern NCA (Dachstein, Tennengebirge, Totes Gebirge, etc., Fig. 1) host several thousand caves of which some are quite huge: presently there are 35 caves where more than $10 \mathrm{~km}$ of passages have been mapped, of which the Schönberg-Höhlensystem is the longest with $148 \mathrm{~km}$ (Pfarr et al., 2019). Most of the subhorizontal passages are arranged in three distinct cave levels (HasekeKnapczyk, 1989; Fischer, 1990) which suggests that the uplift of the NCA occurred in pulses separated 
by periods of tectonic inactivity (Frisch et al., 2001, 2002). The highest and therefore oldest caves are currently located at altitudes between 1,900 and 2,500 m a.s.1. (ruin cave level or Ruinenhöhlen), which, according to Frisch et al. (2001), could have formed already during the formation of the Dachstein Surface in upper Eocene to lower Oligocene. The largest system of caves at altitudes of 1,400-1,800 $\mathrm{m}$ a.s.1. (giant cave level or Riesenhöhlen) have formed after the sedimentation and removal of the
Augenstein Formation in an early stage of the final uplift period of the NCA in Upper Miocene. The third and youngest level is situated close to modern valley floors and is partly still active today (spring cave level or Quellhöhlen).

Based on karst morphologic studies carried out in the Tennengebirge, Audra et al. (2002) assigned a Miocene age to the uppermost Ruinenhöhlen level, while the Riesenhöhlen level was thought to have formed during Upper Miocene to Pliocene times.

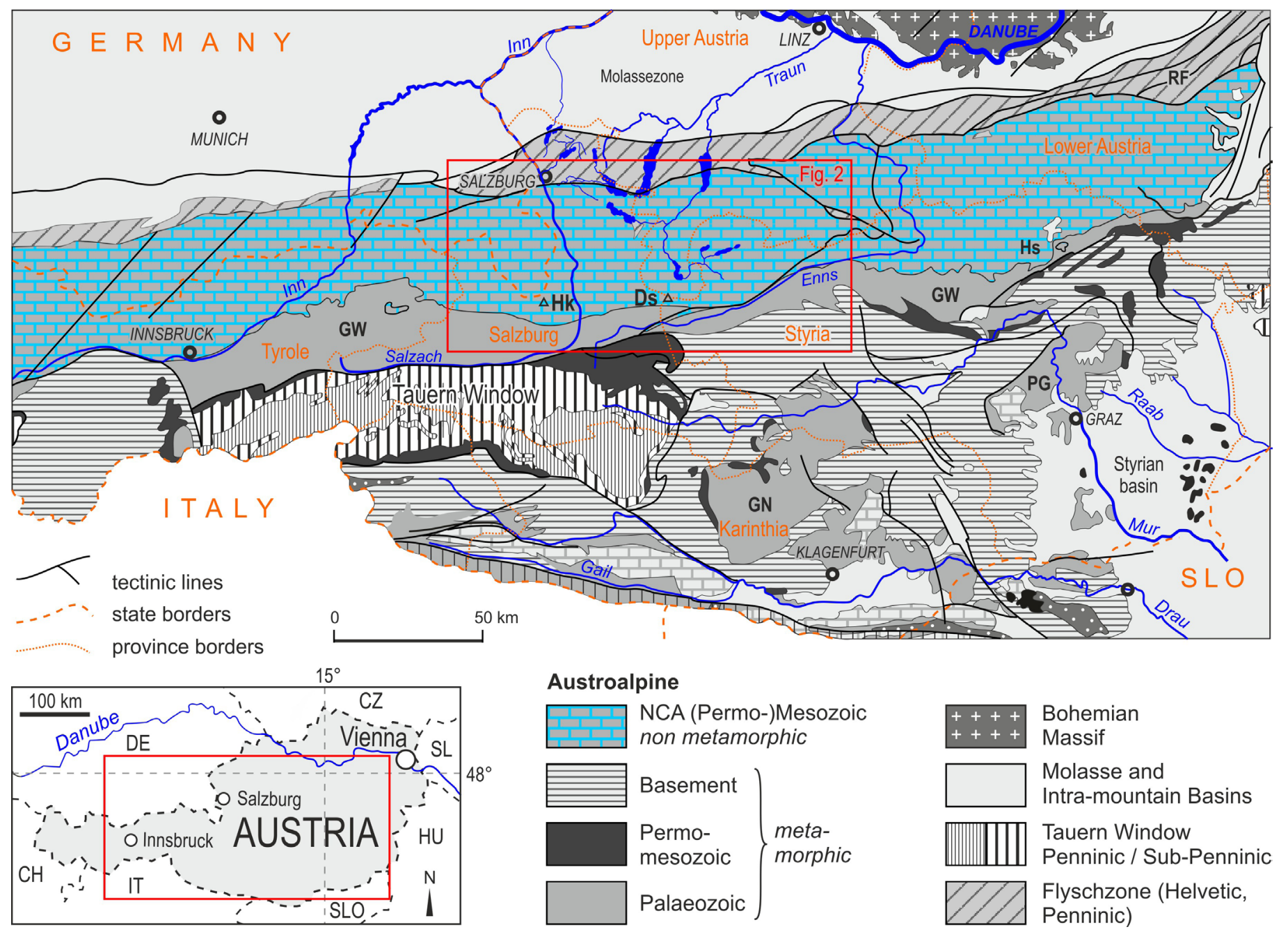

Fig. 1. Simplified map of the Northern Calcareous Alps (NCA) and adjacent areas. Lower left: situation in Austria. GW - Greywacke zone, PG - Paleozoic of Graz, GN - Gurktal nappe (from Frisch et al., 2001, redrawn). Ds: Dachstein; Hk: Hochkönig; Hs: Hochschwab.

\section{SITES AND SAMPLES}

A total of 15 samples were collected from caves situated in the Leoganger Steinberge, Hagengebirge, Untersberg, Tennengebirge, Dachstein, and Totes Gebirge karst massifs (Table 1 and Fig. 2). Reviews of the areas concerning karst and caves can be found in Spötl et al. (2016). Samples collected from Totes Gebirge contained only very small amounts of quartz and proved to be unsuitable for burial age dating, but relatively clean samples have been obtained from Dachstein and Tennengebirge. Additional fieldwork was conducted in the Hoher Göll, but no quartzcontaining sediments were found.

\section{Dachstein}

The Dachstein plateau is the second largest karst plateau in the NCA, covering a surface of approximately
$550 \mathrm{~km}^{2}$. Altitudes range from 2,995 m a.s.1. (Hoher Dachstein) to $508 \mathrm{~m}$ a.s.1. (Hallstatt Lake). The plateau lacks organized surface drainage and is dewatered exclusively by subterranean streams.

Speleogenesis in the area is controlled by gently N-NW dipping bedding planes of the Dachstein Limestone and a complex set of faults. A particular large number of caves and cave passages have been identified on the northern edge of the plateau, which is characterized by steep slopes and vertical walls. The largest caves in the area are the Hirlatzhöhle $(113 \mathrm{~km})$ and the Dachstein-Mammuthöhle $(67 \mathrm{~km})$ both of which feed karst springs which drain into the Hallstatt Lake (Fig. 3).

Mammuthöhle shows one distinct cave level, which belongs to the Riesenhöhlen level, at 1,300-1,450 m a.s.1. Vertical shafts provide connections both to the surface and to the lower active cave levels. Most parts 
Table 1. Samples collected from caves in the Northern Calcareous Alps. Abbreviations for the mountain ranges: D - Dachstein, TG - Totes Gebirge, $\mathrm{T}$ - Tennengebirge, $\mathrm{H}$ - Hagengebirge, $\mathrm{L}$ - Leoganger Steinberge, $\mathrm{U}$ - Untersberg.

\begin{tabular}{|l|c|c|c|c|c|c|}
\hline \multicolumn{1}{|c|}{ Cave } & Cave part & $\begin{array}{c}\text { Elevation } \\
\text { (m a.s.1.) }\end{array}$ & $\begin{array}{c}\text { Sample } \\
\text { ID }\end{array}$ & $\begin{array}{c}\text { Mountain } \\
\text { range }\end{array}$ & $\begin{array}{c}\text { Sampling } \\
\text { date }\end{array}$ & Collected by \\
\hline Dachstein-Mammuthöhle & Derflinger Labyrinth & 1,310 & DMH1 & D & 3.2008 & D. Sahy \& L. Plan \\
\hline Dachstein-Mammuthöhle & Paläotraun & 1,360 & DMH2 & D & 3.2008 & D. Sahy \& L. Plan \\
\hline Dachstein-Mammuthöhle & Paläotraun & 1,370 & DMH3 & D & 3.2008 & D. Sahy \& L. Plan \\
\hline Dachstein-Mammuthöhle & Wassergang, Alter Teil & 1,440 & DMH4 & D & 3.2008 & L. Plan \\
\hline Hirlatzhöhle & & $\sim 1,000$ & HR & D & 3.2008 & D. Sahy \\
\hline Hirlatzhöhle & & 1,060 & HR2 & D & 2.2009 & P. Seethaler \\
\hline Schaflschacht & Quarzgang & 1,480 & SFS & T & 9.2008 & D. Sahy \& P. Pointner \\
\hline Quarzloch & Eingang & 1,120 & QL & T & 9.2008 & D. Sahy \& P. Pointner \\
\hline Gamsställe & Endkammer & 1,120 & GST & T & 9.2008 & D. Sahy \& P. Pointner \\
\hline Tantalhöhle & Sandschluf & 1,500 & TTH & H & 10.2008 & P. Pointner \\
\hline Lamprechtsofen & Hachelgang & 670 & LPH & L & 11.2008 & P. Pointner \\
\hline Fürstenbrunner Quellhöhle & Brillengang & 700 & FBQ & U & 12.2008 & P. Pointner \\
\hline $\begin{array}{l}\text { Pangalaktischer } \\
\text { Donnergurglerschacht }\end{array}$ & & $\sim 1,800$ & PGD & TG & 8.2008 & D. Sahy \\
\hline Illegaler Harem & & 1,640 & ILH1 & TG & $1-6.08 .2008$ & D. Sahy \\
\hline Illegaler Harem & & 1,640 & ILH2 & TG & $1-6.08 .2008$ & D. Sahy \\
\hline
\end{tabular}

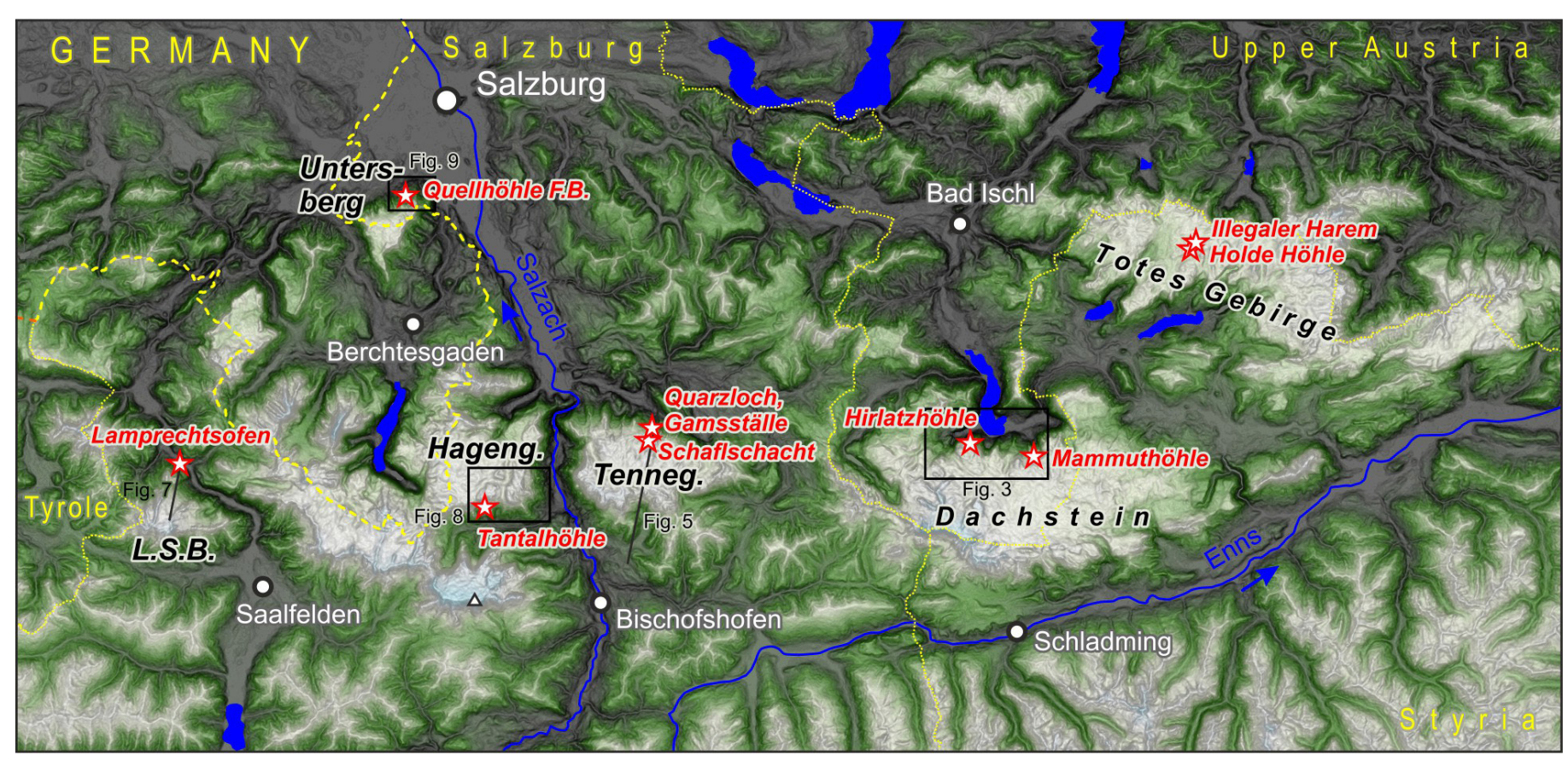

Fig. 2. Digital elevation model of the central NCA, showing the location of the investigated caves.

of Hirlatz cave are developed between 950 and 1,500 m a.s.1. but its relationship to a distinct cave level is not clearly evident.

Allogenic cave sediments consist of well-rounded pebbles and sand layers that may be locally cemented, overlain by laminated silt and clay of glacial origin. Speleothems are very rare above these clastic sediments in Dachstein-Mammuthöhle, massive speleothems are generally older than U/Th limits, and a ${ }^{238 / 235} \mathrm{U}$ equilibrium of one stalagmite suggests an age of more than 1.5 Ma (Frisch et al., 2002). In some parts, the fluvial pebbles show two distinct lithologies. At the base, a thin quartz/quartzite dominated layer occurs, overlain by dominantly carbonate material, which is present in much larger quantities. In general, the two lithologies are rarely found in direct contact inside the cave, but stratigraphical arguments suggest that the quartzite bearing sediment is the older one (removal of the Augenstein sediments from the plateau was followed by erosion of the carbonates). Both the thickness and the grain size of the quartziferous beds is higher in Mammuthöhle where pebbles with diameters of $2-4 \mathrm{~cm}$ are common, while in Hirlatz, quartz pebbles were only found in isolated locations and had diameters of 1-2 $\mathrm{cm}$.

In the Dachstein-Mammuthöhle, all samples consisted of large quartzite pebbles which were collected from different parts of the cave, from altitudes ranging between 1,310-1,440 $\mathrm{m}$ a.s.1. Sample DMH1 was taken from a small passage of the 


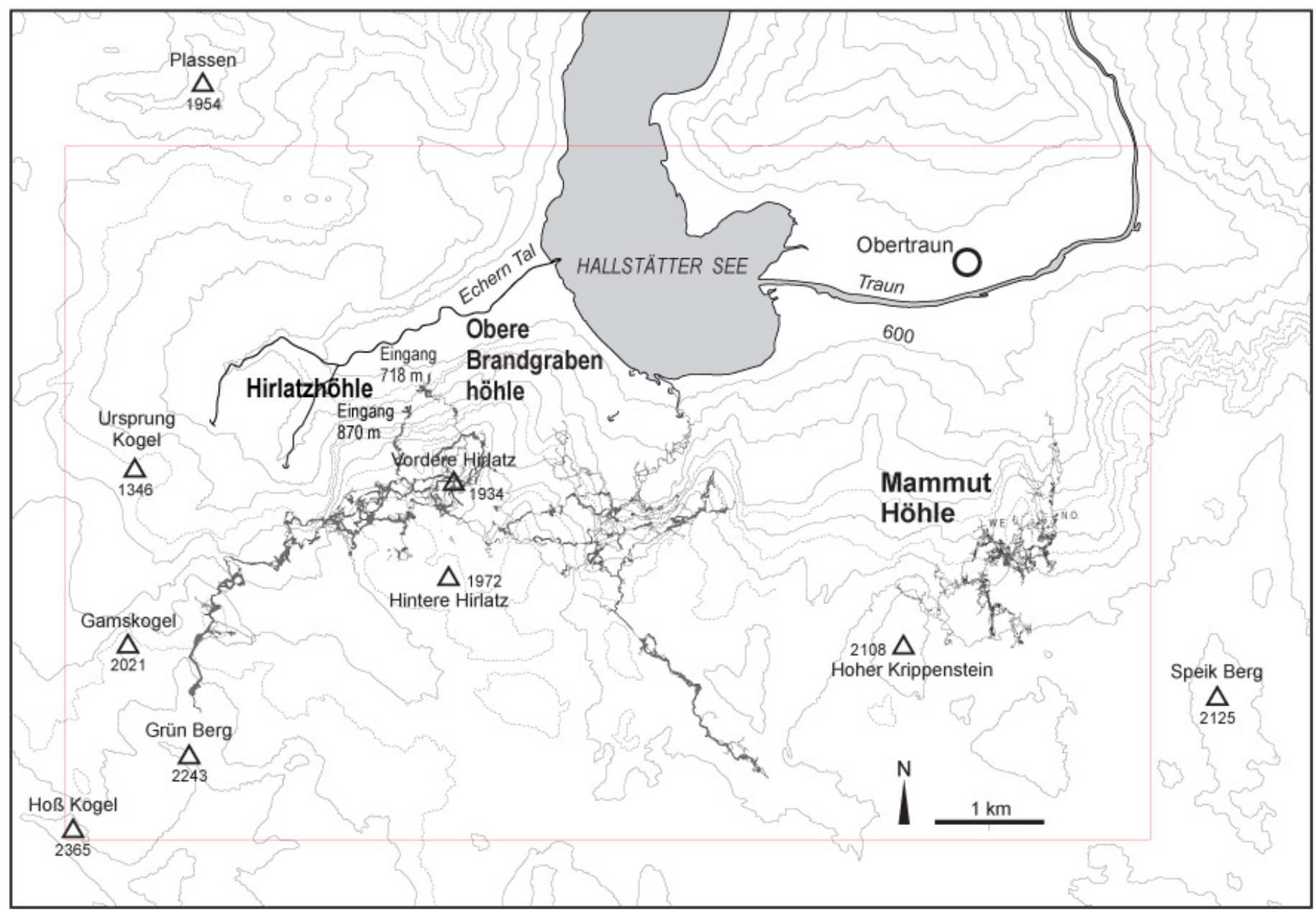

Fig. 3. Location of Hirlatz and Dachstein-Mammuthöhle caves.

Derflinger Labyrinth (Fig. 4) situated at an altitude of $1,310 \mathrm{~m}$, where the quartzite pebbles were cemented to the passage walls. This is one of the few places in the cave where a clear stratigraphic relationship can be established between the quartzite and limestone pebbles.

Samples DMH2 and DMH3 were taken from the Paläotraun passage which is part of the Mammuthöhle show cave. DMH2 was taken at an altitude of $1,360 \mathrm{~m}$, at the eastern end of the Paläotraun passage, from a bed of loose, mixed quartzite and limestone pebbles and sand. Sample DMH3 was taken further along the Paläotraun Passage and consist of large quartzite pebbles that were cemented to the passage floor sculptured by scallops. The scallops are several centimeters to decimeters long and indicate westward drainage under epiphreatic conditions (Plan \& Xaver, 2010).

Sample DMH4 was taken from Wassergang gallery in Alter Teil at an altitude of $1,440 \mathrm{~m}$ and consisted of a deposit of mixed quartzite pebbles and material from the weathering of the Augenstein formation.

The two samples from Hirlatz cave were both collected in the western part of the cave, from a passage that extends between $900-1,000 \mathrm{~m}$ a.s.1. and is interrupted by several large chambers. The area is often flooded during snow-melt or summer storms. Fluvial sediments consisting of rounded limestone pebbles and laminated clay are common. Sample HR1 consists of quartzite pebbles cemented by calcite, while HR2 consist of loose pebbles found on the floor of the passage.

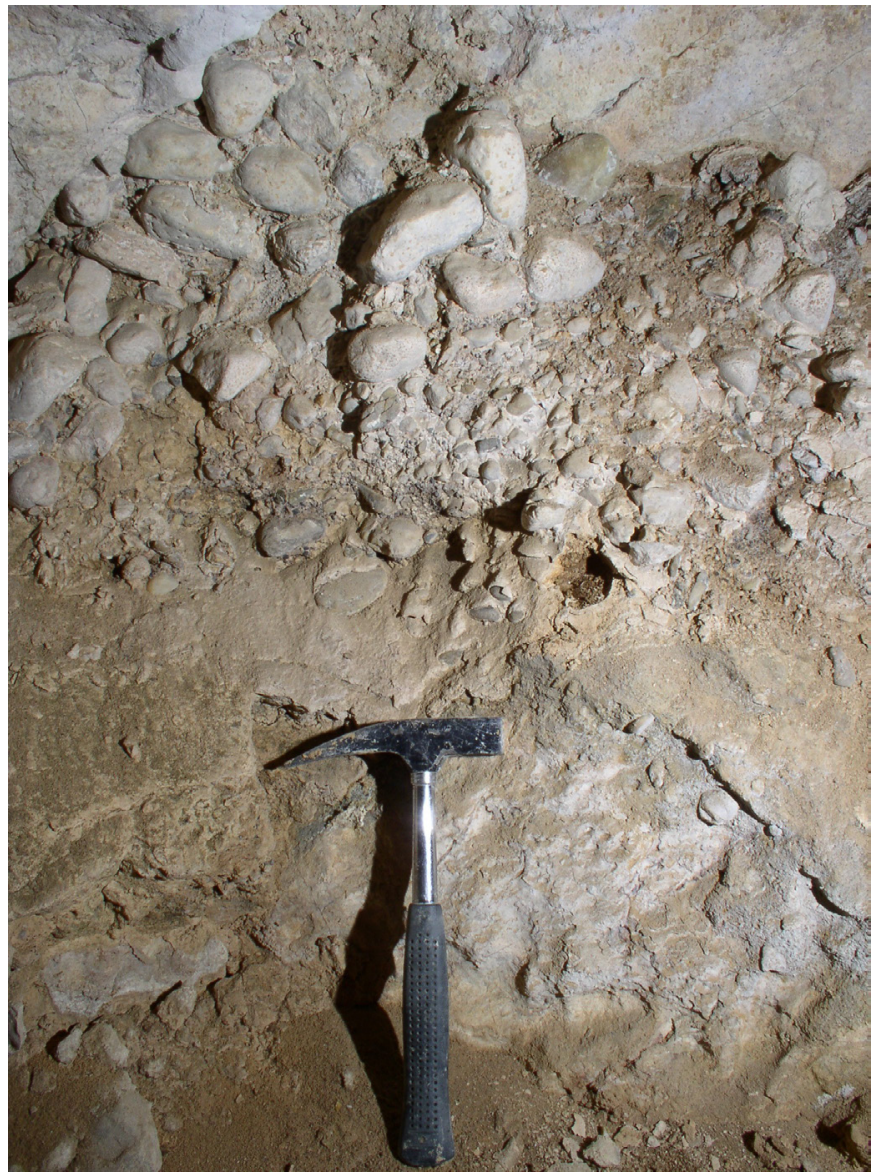

Fig. 4. Contact between quartzite (lower right side) and carbonate (upper left side, larger pebbles) conglomerate in the Derflinger Labyrinth. 


\section{Tennengebirge}

The sampled caves are located on the central northern slope of Tennengebirge (Fig. 5), south of Scheffau am Tennengebirge and approximately $30 \mathrm{~km}$ south of Salzburg. The caves are situated above the Lammer valley which constitutes one of the main waterways of the area.

Based on their altitude between 1,100-1,500 m, it can be assumed that the caves formed during Upper Miocene to Pliocene. The position of the three caves sampled in the area, Schaflschacht (1,480 m a.s.1.), Quarzloch (1,100 m a.s.1.), and Gamsställe (1,120 m a.s.1.) is shown in Fig. 5.

Schaflschacht (1500 m a.s.1.) cave consists of a 10 $m$ deep shaft which gives access to a small horizontal passage with unconsolidated rounded fluvial pebbles. Based on comparative studies with neighboring caves, the Schaflschacht clearly belongs to the Riesenhöhlen level. The sediments consist mainly of quartz pebbles with diameters of 1-2 $\mathrm{cm}$ (sample SFS).

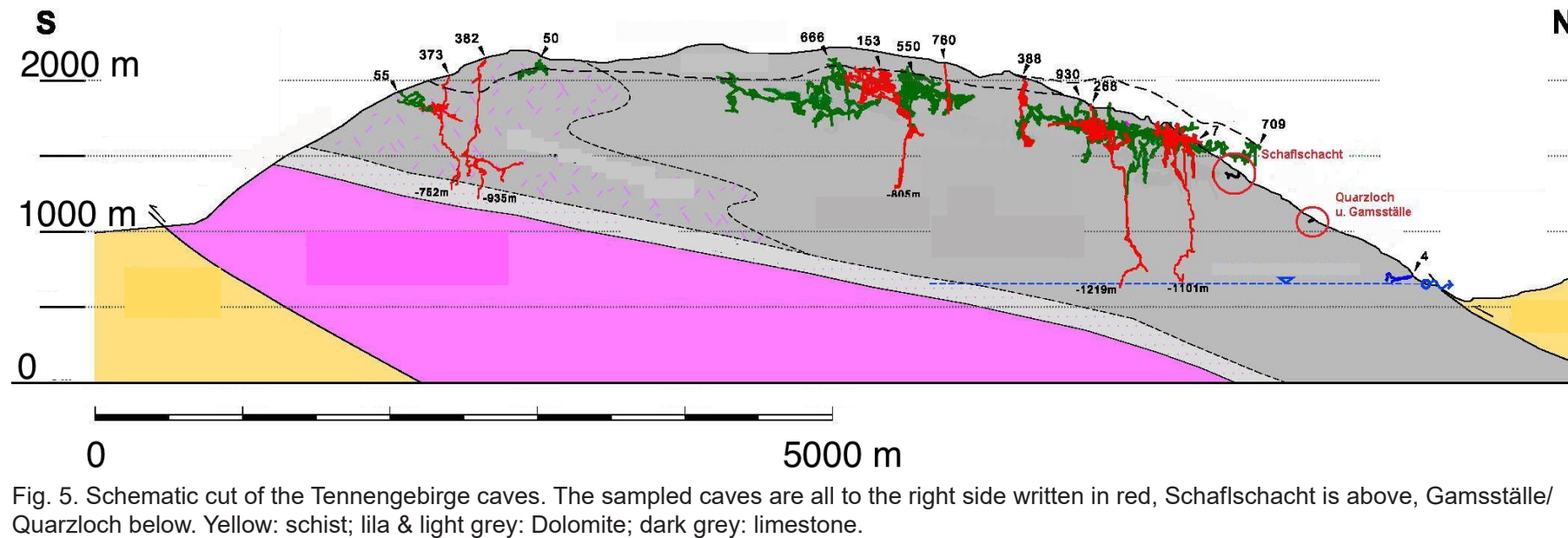

Quarzloch below. Yellow: schist; lila \& light grey: Dolomite; dark grey: limestone.

Quarzloch and Gamsställe are situated relatively close to each other $(0.2 \mathrm{~km})$ at roughly the same altitude, corresponding to the "Bergerhöhlen-Niveau" of Audra et al. (2006) who suggested a Pliocene age. Similar sediments were found in both caves, consisting of interbedded medium and coarse sands and red clays (Fig. 6). Clay is less common in the Quarzloch sediments, but in Gamsställe, the two lithologies form alternating beds with cycle thicknesses of $20-30 \mathrm{~cm}$. Following sedimentary structures, it might be possible that the sediments could have been washed in during glaciations, however there is no absolute proof, and therefore the sediment was sampled. A potential problem with the sediments from Quarzloch is that the sampled site is located relatively close to the surface (about $10 \mathrm{~m}$ away from the cave entrance and overlain by about $10 \mathrm{~m}$ of limestone) so post-burial production could have a significant influence on the age of the sample. Given the fact that Quarzloch and Gamsställe (which is deeper than $10 \mathrm{~m}$ ) are situated close to each other and contain similar sediments, it might be possible to estimate the influence of postburial cosmogenic nuclide production by comparing the age of the two samples.

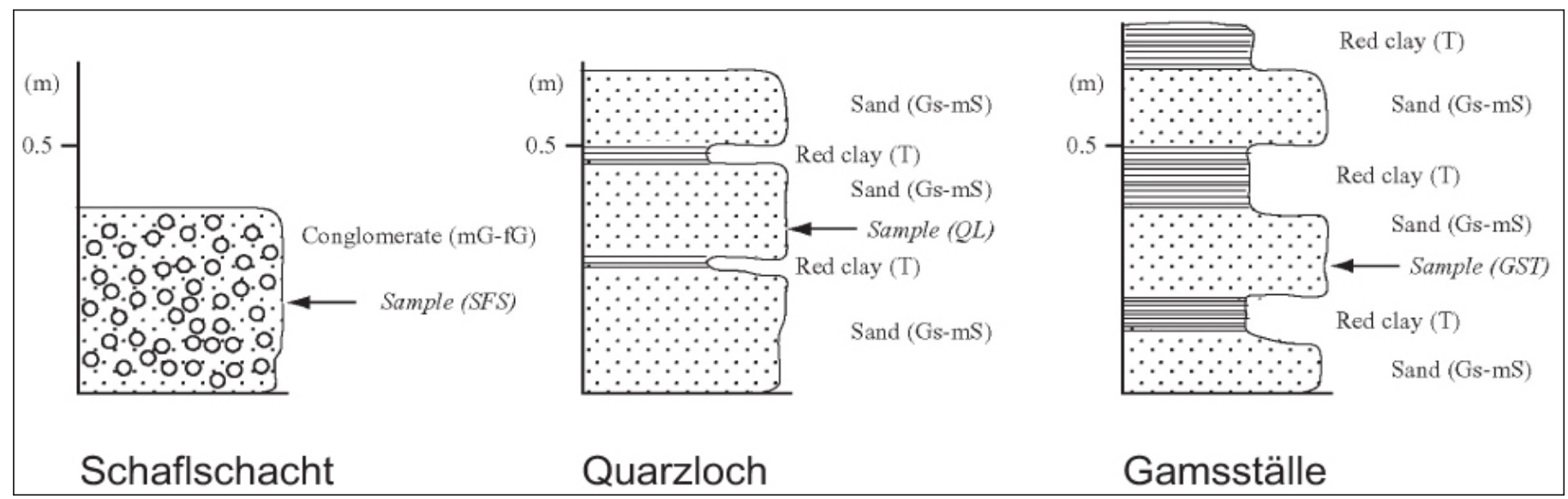

Fig. 6. Sediments sampled in Tennengebirge.

\section{Lamprechtsofen}

The cave is located in the Leoganger Steinberge, between the villages Lofer and Saalfelden. The main entrance opens only few meters above the floor of the river Saalach, at an altitude of $660 \mathrm{~m}$ a.s.1. (Fig. 7). The sample was taken from the lowermost cave level near the spring, which represents the main entrance. Compared to the extensive cave system, the collected pebbles were deposited quite close to the entrance, but nevertheless several hundred meters away from it. The collected grains are noticeably big and reach cobble-size. Fine sediments are lacking. So it is likely, that these sediments are reworked from higher altitudes by the cave river named "Steinbach". It is not excluded that the sampled sediment was washed into the cave from the entrance below, however the presence of several passage jumps makes this possibility rather improbable. 


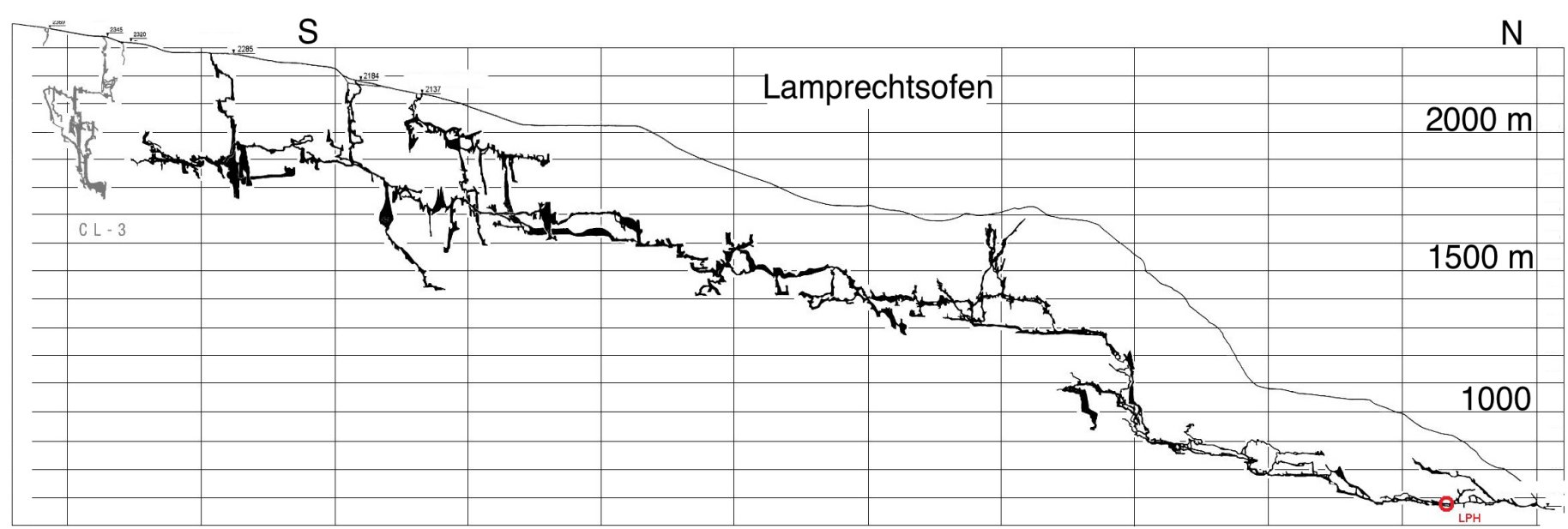

Fig. 7. Cross section of the Lamprechtsofen cave system. The sample was taken from the lowermost horizontal level of the cave, developed at an altitude of $\sim 600 \mathrm{~m}$ a.s.I. (red point); source: www.sktj.pl/epimenides/jaskinie/jask12/pl.gif, modified.

\section{Tantalhöhle}

With its $35 \mathrm{~km}$, Tantalhöhle is the longest cave in the Hagengebirge. Its entrance is located within the southern rock walls at $1,710 \mathrm{~m}$ a.s.1., so this cave belongs to the Riesenhöhlen level (Fig. 8). The depth of the cave is $440 \mathrm{~m}$, with the entrance as the highest point. The sediment sample was taken from the Sandschluf, approximately $1.5 \mathrm{~km}$ inside the mountain.

Normally, clayey-silty sediments dominate within Tantalhöhle. Sandschluf represents a prominent narrow passage where the grain size increases up to coarse sand. The sample was taken from the upper layer of the sediment. Due to lack of a sediment profile, there is no information about the sediment content of deeper layers at this location. Following the local cavers, the sediment was washed in from the surface in a later stage of speleogenesis, but affected by a later erosional phase. This means that the sediment could have been deposited before the last activity of the passage.

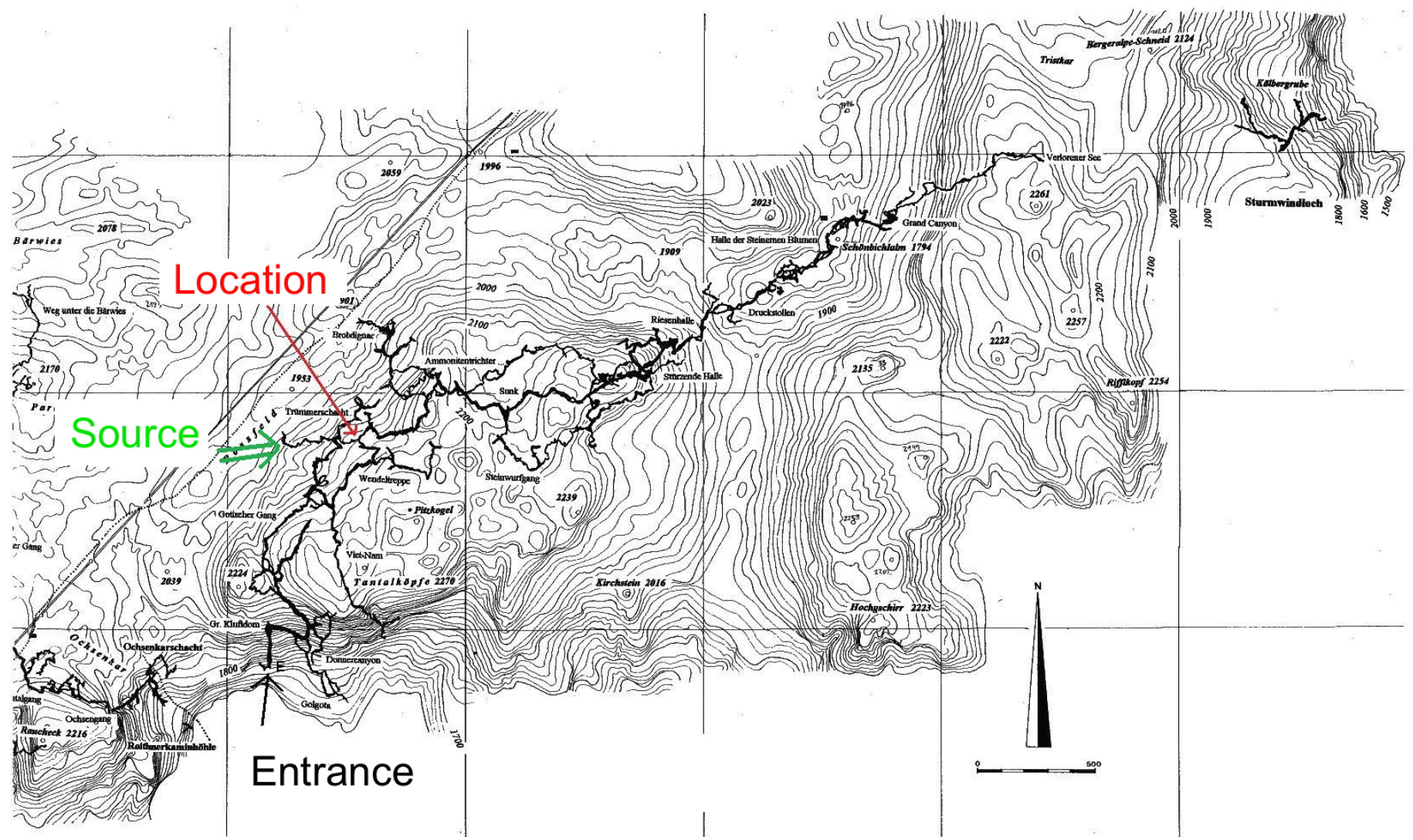

Fig. 8: Location of Tantalhöhle. In red the place "Sandschluf" where the sample was taken, in green the possible way of the sediments coming from the plateau.

\section{Fürstenbrunner Quellhöhle}

The cave is situated in Untersberg, south of Salzburg near the Fürstenbrunn village (Fig. 9). Situated at $600 \mathrm{~m}$ a.s.1. and $120 \mathrm{~m}$ above the valley, the cave is the biggest karst spring of this massif. Its water is captured as drinking water supply for Salzburg. The cave is developed in Dachsteinkalk, has a length of
$3.3 \mathrm{~km}$ and a depth of $135 \mathrm{~m}$. The lowermost level contains the river, higher parts are periodically flooded. An older, permanently dry level is developed approximately $100 \mathrm{~m}$ above the active parts. The sample was taken from a small passage connecting both levels, named "Brillengang". During high discharge, backflooding can still reach the sampling point, but 
there is no current then. The sediments consist mainly of well-rounded sand grains up to coarse gravel. Silt and stones are minor components. The biggest sediment masses occur in a lateral branch and are unstratified. In Untersberg, primarily carbonates are found and quartz-containing sediments are rare. To get some burial ages from this mountain range, this sediment seemed to be the best. Still, there is a possibility that these sediments were brought into the cave via a higher entrance that is blocked now.

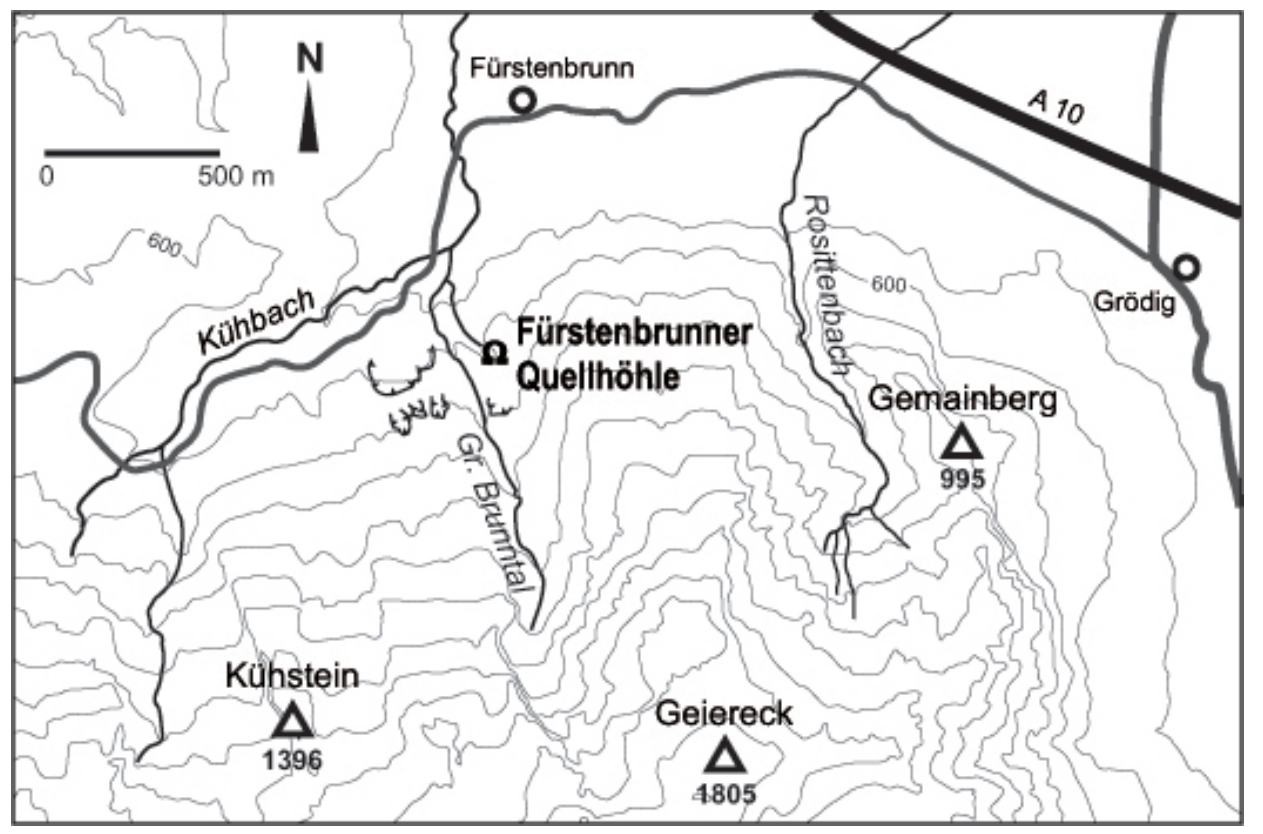

Fig. 9: Location of Fürstenbrunner Quellhöhle.

\section{Totes Gebirge / Hoher Göll}

Other caves in Totes Gebirge and Hoher Göll were investigated and sampled, but yielded no results: three samples were taken from caves on the Totes Gebirge plateau: two from Illegaler Harem and one from Pangalaktischer Donnergurglerschacht, but none of these samples were found to contain significant amounts of quartz. Horizontal passages in Hoher Göll exist in Kammerschartenhöhle, at an elevation of $\sim 1600 \mathrm{~m}$ a.s.1., but contain no fluvial quartz pebbles.

\section{METHODS}

In the laboratory, about $100 \mathrm{~g}$ of quartz were extracted and purified from bulk samples by magnetic and density separation and selective chemical dissolution. Quartz was dissolved in a 5:1 solution of concentrated $\mathrm{HF}$ and $\mathrm{HNO}_{3}$ and spiked with about $0.25 \mathrm{mg}{ }^{9} \mathrm{Be}$. Al and Be were separated and purified by ion chromatography and selective precipitation. Precipitates were oxidized and mixed with metal powder for accelerator mass spectrometry (AMS). ${ }^{10} \mathrm{Be} /{ }^{9} \mathrm{Be}$ and ${ }^{26} \mathrm{Al} /{ }^{27} \mathrm{Al}$ nuclide ratios in the sample and procedural blanks were measured at Purdue University in West Lafayette (USA). Stable aluminium concentrations were determined by ICP-OES. The stated errors are $1 \sigma$ calculated from AMS and ICPOES uncertainties.

The measurement of the procedural blanks yielded ${ }^{10} \mathrm{Be} /{ }^{9} \mathrm{Be}$ ratios $\leq 5 \times 10^{-15}$ and ${ }^{26} \mathrm{Al} /{ }^{27} \mathrm{Al}$ ratios of $<0$ to $13 \times 10^{-15}$. With the exception of the relatively high $\mathrm{Al}$ blank (relativized by the high error of $\pm 18 \times 10^{-15}$ ), the blanks thus show that the measurements were good and the standards clean.

The isotope concentrations can also be used to infer paleo-erosion rates of the source area prior to burial of the clasts. This is accomplished by backward modeling the quantity of nuclides present prior to the burial coupled with local production rate estimates.

The pre-burial ${ }^{26} \mathrm{Al} /{ }^{10} \mathrm{Be}$ ratio $(\sim 6.8: 1)$ is basically not influenced by production rate and thus elevation (Nishiizumi et al., 1989; Stock et al., 2005b) and therefore burial ages remain unaffected by altitude changes in the source area. However, the preburial erosion rates are based on measured isotope concentrations and elevation-dependant production rates. They are therefore only rough approximations.

\section{RESULTS}

Table 2 gives the results of the measurements. All results were normalized for a ${ }^{10} \mathrm{Be}$ half-life of $1.39 \mathrm{Ma}$ (Chmeleff et al., 2009, Korschinek et al., 2009). The uncertainties represent the analytical error only. The erosion rates are approximate, since the altitude and further shielding problems at the surface are unknown.

The first impression is that almost all the caves that were sampled yielded ages from the Pliocene and late Miocene. This, however, does not reflect the general situation: sampling was specifically concentrated on caves whose altitude above the baselevel suggested ages that were within some millions of years. Clearly young caves and clearly old "Ruinenhöhlen" caves were voluntarily omitted, with the exception of the Fürstenbrunner Quellhöhle and Lamprechtsofen, where passages of different age are present. The distribution of the ages is therefore strongly biased by sampling.

There are three samples that yielded no age. The upper age limit is given by the gradual decay of the nuclides; after some millions of years, there are almost no nuclides left to be counted, and then the 
Table 2. Results of the ${ }^{26} \mathrm{Al} /{ }^{10} \mathrm{Be}$ measurements and the inferred ages as well as erosion rates. No blank correction was applied. The altitude of catchment is an estimate used to infer nuclide production rates at the surface, which in turn gives hints about the erosion rate at the surface where the sample comes from (see text).

\begin{tabular}{|c|c|c|c|c|c|c|c|c|}
\hline Cave & Sample & $\begin{array}{c}\text { Altitude } \\
\text { catchment }\end{array}$ & $\begin{array}{l}\text { Altitude } \\
\text { in cave }\end{array}$ & $\begin{array}{c}{ }^{26} \mathrm{Al} \\
\left(10^{3} \mathrm{at} / \mathrm{g}\right)\end{array}$ & $\begin{array}{c}{ }^{10} \mathrm{Be} \\
\left(10^{3} \mathrm{at} / \mathrm{g}\right)\end{array}$ & ${ }^{26} \mathrm{Al} /{ }^{10} \mathrm{Be}$ & $\begin{array}{l}\text { Burial age } \\
\text { (Ma) }\end{array}$ & Inh. Erosion \\
\hline \multirow{4}{*}{ Dachstein } & DMH1 & 1,700 & 1,310 & $5.3 \pm 4.6$ & $12.4 \pm 1.25$ & $0.43 \pm 0.37$ & $5.75 \pm 1.31$ & $51 \pm 42$ \\
\hline & DMH2 & 1,700 & 1,360 & $7.1 \pm 4$ & $8.6 \pm 0.95$ & $0.83 \pm 0.47$ & $4.37 \pm 0.95$ & $150 \pm 81$ \\
\hline & DMH3 & 1,700 & 1,400 & $0 \pm 0$ & $18.4 \pm 1.67$ & $0 \pm 0$ & beyond age limit & \\
\hline & DMH4 & 1,700 & 1,430 & $0 \pm 0.2$ & $10.2 \pm 0.93$ & $0 \pm 0$ & beyond age limit & \\
\hline \multirow{2}{*}{ Hirlatz } & HR & 1,700 & $\sim 1,000$ & $38 \pm 10$ & $68.2 \pm 2.18$ & $0.55 \pm 0.15$ & $5.16 \pm 0.49$ & $12 \pm 3$ \\
\hline & HR2 & 1,700 & 1,060 & $21 \pm 9$ & $79.4 \pm 3.29$ & $0.27 \pm 0.12$ & $6.6 \pm 0.72$ & $5 \pm 2$ \\
\hline Schaflschacht & SFS & 2,100 & 1,480 & $17 \pm 11$ & $63.2 \pm 2.62$ & $0.27 \pm 0.18$ & $6.65 \pm 0.95$ & $8 \pm 4$ \\
\hline Quarzloch & QL & 1,100 & 1,120 & $0 \pm 0$ & $6.89 \pm 1.24$ & $0 \pm 0$ & beyond age limit & \\
\hline Gamsställe & GST & 1,100 & 1,120 & $64 \pm 43$ & $12.6 \pm 2.52$ & $5.11 \pm 3.58$ & $0.59 \pm 1.13$ & $445 \pm 301$ \\
\hline Tantalhöhle & TTH & 2,000 & 1,500 & $323 \pm 81$ & $496 \pm 35.1$ & $0.65 \pm 0.17$ & $4.67 \pm 0.49$ & $2 \pm 1$ \\
\hline Lamprechtsofen & LPH & 2,000 & 670 & $47 \pm 8$ & $23.1 \pm 1.87$ & $2.04 \pm 0.37$ & $2.49 \pm 0.35$ & $177 \pm 35$ \\
\hline Fürstenb. Q. & FBQ & 1,500 & 700 & $30 \pm 35$ & $17.8 \pm 3.56$ & $1.7 \pm 2.02$ & $2.87 \pm 1.56$ & $131 \pm 72$ \\
\hline
\end{tabular}

age calculations do not get a meaningful result. This is the case for samples DMH3 and DMH4 from Dachstein-Mammuthöhle. There, no more ${ }^{26} \mathrm{Al}$ counts could be recorded, and thus an age calculation is no more possible. However, the presence of ${ }^{10} \mathrm{Be}$ in these three samples shows that the sediment was at the surface once. A good guess on the age of these samples would be a deposition underground that happened in the Upper Miocene (5-10 Ma ago). After $10 \mathrm{Ma}$, all ${ }^{10} \mathrm{Be}$ would have been decayed. Theoretically, it would be possible to estimate a minimum burial age, taking into account the surface production rate and the average residence time at the surface (taken from other samples with known age). However, since both are only gross estimations, and DMH 1 and 2 gave old ages, we think it is misleading to indicate a minimum burial age.

A special case is the Quarzloch, which contains ${ }^{10} \mathrm{Be}$, but no ${ }^{26} \mathrm{Al}$. The first assumption is that this sediment had the same fate as DMH3 and DMH4. However, the cave is rather short and the sediment deposited is close to the surface, so that the interpretation is that the few nuclides present in the sample were rather initiated by irradiation from the surface.

Two samples present ages that are above the commonly assumed upper age limit of the method. Sample HR2 from Hirlatz cave as well as SFS from Schaflschacht show ages of 6.6 Ma. In HR2, however, both the ${ }^{26 / 27} \mathrm{Al}$ ratio measured $\left(2 \times 10^{-14}\right)$ as well as the absolute ${ }^{26} \mathrm{Al}$ numbers $\left(21 \times 10^{3}\right)$ and the backcalculated initial isotope ratio are well within a reasonable range. We assume that although the age calculated is high, it is still reasonable. The SFS sample is a bit different in that the ${ }^{26 / 27} \mathrm{Al}$ ratio measured is much lower $\left(3 \times 10^{-15}\right)$, and the final error is larger.

\section{EXPECTATIONS ON RELATIVE CHRONOLOGY}

Following Frisch et al. (2008) as well as Audra et al. (2002), we expected an Eocene to Miocene age for the ruin level caves, an upper Miocene age for the giant level caves, a Pliocene age for the "Bergerhöhlen" level found in Tennengebirge at an altitude of 900-1100 $\mathrm{m}$ asl, and a Plio-Pleistocene age for the Quellhöhlen level.

This translates into the following ages: The $\mathrm{DMH}$ samples, SFS and Tantalhöhle are expected to be Upper Miocene, the Hirlatz samples rather PlioPleistocene, Quarzloch and Gamsställe Pliocene, and Lamprechtsofen and FBQ clearly Plio-Pleistocene again. From in-cave stratigraphy, DMH is expected to be old also. Tantalhöhle is, from the stratigraphic position, expected to give the age of the last flooding of the passage before its fossilization, whereas the Hirlatz samples might be rather young (still within reach of the floods). Both Lamprechtsofen and FBQ might be young, but they were sampled at locations where this possibility should be minimized. The sediments of Quarzloch and Gamsställe are expected to be contemporaneous, since they are very comparable in facies and grain size distribution, however their rather low position make it possible that they were deposited during the Pleistocene glaciations.

\section{DISCUSSION}

There is always the question whether the obtained ages mean anything: sand and cobbles are mobile, and floods may well dislocate old sand deposits, mix them, and deposit in a much younger cave section, so that any age dating is prone to be erroneous.

Indeed, polycyclic hydrologic activity is common in Alpine caves. Often, existing galleries are reused by younger vadose waters from intersecting canyons. Another phenomenon causing sediment (re)deposition is backflooding during the Pleistocene, when the valleys were occupied by partly more than $1 \mathrm{~km}$ of ice.

The lack of extraordinary young ages at high elevations (except from Gamsställe) suggests that among the analyzed samples there was no surface material that was washed into a preexisting gallery at a later stage. However, the samples from Fürstenbrunner Quellhöhle and Lamprechtsofen are surprisingly old despite their low elevation and do 
not fit into the picture. We interpret them as old cave sediments that were eroded from higher locations and redeposited at the sample location relatively lately.

With the exception of the latter two, the explanation fits to the experience from the Siebenhengste example (west-central Switzerland; Häuselmann et al., 2007): all the young passages contained only young sediments, whereas old passages contained old and young sediments. This means that deposition occurs over the whole age span of a cave, whereas remobilization results in a washout of the sediments to the surface. This process is currently observed in Hölloch cave (Switzerland), where old sediments were mobilized by the huge 2005 flood (320 m above normal lowstand, $100 \mathrm{~m}$ above historic highstands) and are now continually transported towards the entrance of the cave.

The DMH samples with their lower Pliocene age are a bit younger than expected, but still within the possible range, especially when considering their (for Riesenhöhlen) rather low altitude.

The Hirlatz ages are very high, both regarding the sample position close to the active parts, and the absolute altitude. It is likely that these again are old, reworked sediments that were brought into lower passages by exceptional floods.

The Schaflschacht and Tantalhöhle ages again are in good accordance, but the Gamsställe shows an age that is too young. The sample, which, as said above, was possibly been washed in during glaciations, is now clearly Quaternary.

If we assume that the sediments were washed into their position from the surface at the time indicated by their age (that is, they were not reworked from an older cave level), and again assuming that they were deposited at approximately the base level, as indicated in several cases by passage morphology, we can tentatively calculate a valley deepening rate. Table 3 shows that deepening rates that can be used are between 0.12 to $0.21 \mathrm{~km} / \mathrm{Ma}$, and that the older ages yield lower deepening rates than the younger ones.

\section{Comparison with previous studies}

While age dating with the U/Th method on stalagmites (in connection with climate research) is widespread, cosmogenic age dating is rare. In Austria, a first attempt on sediments from Eisriesenwelt yielded no results (Frisch et al., 2002), and only Wagner et al. (2010) presented coherent and logical data on the incision of the Mur river north of Graz in an unglaciated area being $0.12 \mathrm{~km} / \mathrm{Ma}$ at average for the last $4 \mathrm{Ma}$. Comparison with other published cosmogenic ages in the Alps (Häuselmann et al., 2007) shows a comparable age range, with valley deepening rates in this glaciated part of the Alps ranging from $0.12 \mathrm{~km} / \mathrm{Ma}$ (Pliocene) to rapid $1.2 \mathrm{~km} / \mathrm{Ma}$ after the mid-Pleistocene transition around $1 \mathrm{Ma}$ ago.

Meyer et al. (2009) dated speleothems in a cave in the Allgäu Mountains (NCA) to 2.16 to $2.12 \mathrm{Ma}$ by $\mathrm{U} / \mathrm{Pb}$. The cave's altitude is at $2,500 \mathrm{~m}$ a.s.1. They concluded that uplift and erosion rate in that part of the NCA amounts to roughly 0.75 and $0.5 \mathrm{~km} / \mathrm{Ma}$, respectively.

Frisch et al. (2008), in the paper on the geomorphic evolution of the Eastern Alps, concluded that the averaged Mio-Pliocene erosion rate was increasing from 0.1 to $0.2 \mathrm{~km} / \mathrm{Ma}$, and to $0.3 \mathrm{~km} / \mathrm{Ma}$ in the Quaternary.

A regional cave study in Kraushöhle (De Waele et al., 2009) indicates, however with a large error, a minimal uplift rate of $0.44 \mathrm{~km} / \mathrm{Ma}$ in that area. This data points indeed to an accelerated deepening rate early in the Quaternary.

Comparing the above deepening rates with our results, we have first to note that in contrast to the data published by Häuselmann et al. (2007), the rates obtained here are the total deepening rates from sample deposition to present-day status. Notwithstanding this averaged rate, the valley deepening rates presented here are in good accordance with both the conclusions of Frisch et al. (2008) as well as the results for the older speleogenetic phases of the Siebenhengste before the mid-Pleistocene transition.

Regarding the geomorphic history of the Northern Calcareous Alps, our results also confirm reasonably well the evolution described by Frisch et al. (2002) and Audra et al. (2006) as well as Kuhlemann et al. (2001). Upper Miocene to Lower Pliocene ages of the giant cave level of the NCA are therefore reasonable.

Table 3. Approximate valley deepening rates of the base levels in the respective caves. To be complete, also the cave samples that clearly were reworked are calculated.

\begin{tabular}{|c|c|c|c|c|c|c|}
\hline Cave & Sample & $\begin{array}{l}\text { Depositional } \\
\text { altitude }\end{array}$ & $\begin{array}{l}\text { Present-day } \\
\text { altitude }\end{array}$ & $\begin{array}{c}\text { Burial age } \\
\text { (Ma) }\end{array}$ & $\begin{array}{c}\text { Deepening rate } \\
\text { (m/Ma) }\end{array}$ & Remarks \\
\hline \multirow{4}{*}{ Dachstein } & DMH1 & 1310 & 508 & $5.75 \pm 1.31$ & 139 & \\
\hline & DMH2 & 1360 & 508 & $4.37 \pm 0.95$ & 195 & \\
\hline & DMH3 & 1400 & 508 & $0 \pm 0$ & & \\
\hline & DMH4 & 1430 & 508 & $0 \pm 0$ & & \\
\hline \multirow{2}{*}{ Hirlatz } & HR & 1000 & 508 & $5.16 \pm 0.49$ & 95 & reworked? \\
\hline & HR2 & 1060 & 508 & $6.6 \pm 0.72$ & 84 & reworked? \\
\hline Schaflschacht & SFS & 1480 & 660 & $6.65 \pm 0.95$ & 123 & \\
\hline Quarzloch & QL & 1120 & 660 & $0 \pm 0$ & & \\
\hline Gamsställe & GST & 1120 & 660 & $0.59 \pm 1.13$ & 780 & glacial \\
\hline Tantalhöhle & TTH & 1500 & 500 & $4.67 \pm 0.49$ & 214 & \\
\hline Lamprechtsofen & LPH & 670 & 660 & $2.49 \pm 0.35$ & 4 & reworked \\
\hline Fürstenb. Q. & FBQ & 700 & 425 & $2.87 \pm 1.56$ & 96 & reworked \\
\hline
\end{tabular}


The results of our study confirm the data from Szekely (2003) and indicate a somehow slower erosion rate than Kuhlemann et al. (2001). The data from the Central Alps (Bernet et al. 2001) are much higher than ours, but it is generally assumed that the Eastern Alps have a different (and slower) exhumation/incision history.

\section{CONCLUSIONS}

Cosmogenic dating of caves in the Northern Calcareous Alps of Austria yielded somehow mixed results. While some of the ages obtained correspond to the expectations that the Riesenhöhlen level is Upper Miocene, and Quellhöhlen level is Plio-Pleistocene (DMH, including the two samples above the age limit, Schaflschacht, and Tantalhöhle), others seem to give ages too old (Hirlatz, FBQ, Lamprechtsofen). Finally, one cave (Gamsställe) yielded a Quaternary age and thus confirms the assumption that the corresponding sediment was washed in during a glacial highstand.

The obtained valley deepening rates are in good agreement with results from the older parts of Siebenhengste and with the conclusion of Frisch et al. (2008). Deepening rates that can be used are between 0.12 to $0.21 \mathrm{~km} / \mathrm{Ma}$, and rates increase from Miocene towards Quaternary.

\section{ACKNOWLEDGEMENTS}

First thanks go to Herta Effenberger (University of Vienna) who let us use space for a laboratory, as well as the whole Geozentrum at Vienna University for the help and welcome to our project. The PrimeLab of Purdue University (Indiana, USA) is thanked for sample processing and measuring the isotopes. The Austrian Science Fund FWF is thanked for funding the project (P 19362-N10). Contributions from Diana Sahy (Fieldwork and partial treatment of the samples) and Helene Pfalz-Schwingenschlögl (figure drawings) were instrumental in obtaining the results and the present article. Philippe Audra and Jo de Waele are thanked for thoughtful reviews.

Autorship statement: $\mathrm{PH}$ and MF designed and directed the study. PH calculated the ages, LP and PP were involved in fieldwork and field interpretation. $\mathrm{PH}$ and LP wrote the paper with substantial input form PP.

\section{REFERENCES}

Audra, Ph., Quinif, Y., Rochette, P., 2002. The genesis of the Tennengebirge karst and caves (Salzburg, Austria). Journal of Cave and Karst Science, 64 (3), 153-164.

Audra, Ph., Bini, A., Gabrovšek, F., Häuselmann, Ph., Hobléa, F., Jeannin, P.-Y., Kunaver, J., Monbaron, M., Šušteršič, F., Tognini, P., Trimmel, H., Wildberger, A., 2006. Cave genesis in the Alps between the Miocene and today: a review. Zeitschrift für Geomorphologie, 50 (2), 153-176.

Balco, G., Soreghan, G.S., Sweet, D.E., Marra, K.R., Bierman, P.R., 2013. Cosmogenic-nuclide burial ages for Pleistocene sedimentary fill in Unaweep Canyon, Colorado, USA. Quaternary Geochronology, 18, 149-157. https://doi.org/10.1016/j.quageo.2013.02.002
Bernet, M., Zattin, M., Garver, J.I., Brandon, M.T., Vance, J.A, 2001. Steady-state exhumation of the European Alps. Geology, 29, 35-38.

https://doi.org/10.1130/0091-7613(2001)029\% 3C0035:SSEOTE\%3E2.0.CO;2

Cederbohm, C.E., Sinclair, H.D., Schlunegger, F., Rahn, M., 2004. Climate-induced rebound and exhumation of the European Alps. Geology, 32, 709-712. https://doi.org/10.1130/G20491.1

Chmeleff, J., von Blanckenburg, F., Kossert K., Jakob, D., 2009. Determination of the ${ }^{10} \mathrm{Be}$ half-life by multicollector ICP-MS and liquid scintillation counting. Nuclear Instruments and Methods in Physics Research B, 268, 192-199.

https://doi.org/10.1016/j.nimb.2009.09.012

Columbu, A., De Waele, J., Forti, P., Montagna, P., Picotti, V., Pons-Branchu, E., Hellstrom, J., Bajo, P., Drysdale, R., 2015. Gypsum caves as indicators of climate-driven river incision and aggradation in a rapidly uplifting region. Geology, 43 (6), 539-542. https://doi.org/10.1130/G36595.1

De Waele, J., Plan, L., Audra, P., Rossi, A., Spötl, C., Polyak, V., McIntosh, B., 2009. Kraushöhle (Austria): morphology and mineralogy of an alpine sulfuric acid cave. Proceedings of the 15th International Congress of Speleology, Kerrville, Part 2, p. 31-37.

Fischer, K., 1990. Höhlenniveaus und Altreliefgenerationen in den Berchtesgadener Alpen. Mitteilungen der Geografischen Gesellschaft München, 75, 47-59.

Frisch, W., Kuhlemann, J., Dunkl, I. \& Brügel, A., 1998. Palinspastic reconstruction and topographic evolution of the Eastern Alps during late Tertiary tectonic extrusion. Tectonophysics, 297 (1-4), 1-15. https://doi.org/10.1016/S0040-1951(98)00160-7

Frisch, W., Kuhlemann, J., Dunkl, I., Szekely, B., 2001. The Dachstein paleosurface and the Augenstein Formation in the Northern Calcareous Alps - a mosaic stone in the geomorphological evolution of the Eastern Alps. International Journal of Earth Science, 90, 500518. https://doi.org/10.1007/s005310000189

Frisch, W., Kuhlemann, J., Dunkl, I., Szekely, B., Vennemann, T., Rettenbacher, A., 2002. Dachstein-Altfläche, Augenstein-Formation und Höhlenentwicklung - die Geschichte der letzten 35 Millionen Jahre in den zentralen Nördlichen Kalkalpen. Die Höhle 53 (1), 1-36.

Frisch, W., Kuhlemann, J., Dunkl, I., Szekely, B., 2008. Die geomorphologische Entwicklung der Ostalpen. Mitteilungen der Österreichischen Geografischen Gesellschaft, 150, 123-162.

Gosse, J.C., Phillips F.M., 2001. Terrestrial in situ cosmogenic nuclides: Theory and application. Quaternary Science Reviews, 20 (14), 1475-1560. https://doi.org/10.1016/S0277-3791(00)00171-2

Granger, D.E., Muzikar, P.F. 2001. Dating sediment burial with cosmogenic nuclides: Theory, techniques, and limitations. Earth and Planetary Science Letters, 188 (1-2), 269-281.

https://doi.org/10.1016/S0012-821X(01)00309-0

Haseke-Knapczyk, H., 1989. Der Untersberg bei Salzburg. Die ober- und unterirdische Karstentwicklung und ihre Zusammenhänge. Ein Beitrag zur Trinkwassererforschung. Österreichische Akademie der Wissenschaften, MaB-Reihe, Bd. 15.

Häuselmann, Ph., Granger, D.E., Jeannin, P.-Y., Lauritzen, S.E., 2007. Abrupt glacial valley incision at $0.8 \mathrm{Ma}$ dated from cave deposits in Switzerland. Geology, 35 (2), 143-146. https://doi.org/10.1130/G23094A 
Häuselmann, Ph., Mihevc, A., Pruner, P., Horáček, I., Čermák, S., Hercman, H., Sahy, D., Fiebig, M., Zupan Hjn, N. \& Bosák, P., 2015. Snežna jama (Slovenia): interdisciplinary dating of cave sediments and implication for landscape evolution. Geomorphology, 247, 10-24.

https://doi.org/10.1016/j.geomorph.2014.12.034

Korschinek, G., Bergmaier, A., Faestermann, T., Gerstmann, U.C., Knie, K., Rugel, G., Wallner, A., Dillmann, I., Dollinger, G., Lierse von Gostomski, Ch., Kossert, K., Maiti, M., Poutivtsev, M., Remmel, A., 2009. A new value for the half-life of ${ }^{10} \mathrm{Be}$ by heavy-ion elastic recoil detection and liquid scintillation counting. Nuclear Instruments and Methods in Physics Research B, 268, 187-191. https://doi.org/10.1016/j.nimb.2009.09.020

Kuhlemann, J., 2000. Post-collisional sediment budget of circum-Alpine basins (Central Europe). Memorie delle Scienze Geologiche Padova, 52, 1-91.

Kuhlemann, J., Frisch, W., Dunkl, I., 2001. The Oligocene geologic and paleotopographic evolution of the Eastern Alps. In: Piller, W.E., Rasser, M.W. (Eds.), Paleogene of the Eastern Alps (Schriftenreihe der Erdwissenschaftlichen Kommissionen, 14), p. 129-152.

Langenscheidt, E., 1986. Höhlen und ihre Sedimente in den Berchtesgadener Alpen. Nationalpark Berchtesgaden Forschungsberichte, 10, 1-95.

Lichtenecker, N., 1924. Das Bewegungsbild der Ostalpen. Naturwissenschaften, 13, 739-743. https://doi.org/10.1007/BF01558826

Lichtenecker, N., 1926. Die Rax. Geografischer Jahresbericht von Österreich, 13, 150-170.

Meyer, M.C., Cliff, R.A., Spötl, C., Knipping, M., Mangini, A., 2009. Speleothems from the earliest Quaternary: Snapshots of paleoclimate and landscape evolution at the northern rim of the Alps. Quaternary Science Reviews, 28, 1374-1391. https://doi.org/10.1016/j.quascirev.2009.01.010
Nishiizumi, K., Winterer, E.L., Kohl ,C.P., Klein, J., Middleton, R., Lal, D., Arnold, J.R., 1989. Cosmic ray production rates of ${ }^{10} \mathrm{Be}$ and ${ }^{26} \mathrm{Al}$ in quartz from glacially polished rocks. Journal of Geophysical Research, 94, 17907-17915. https://doi.org/10.1029/JB094iB12p17907

Pfarr, T., Seebacher, R., Plan, L., 2019. Longest and deepest caves of Austria. www.hoehle.org/long\&deep. php [accessed 24/1/2019].

Plan, L., Xaver, A., 2010. Geomorphologische Untersuchung und genetische Interpretation der Dachstein-Mammuthöhle (Österreich). Die Höhle, 61, 18-38.

Spötl, C., Plan, L., Christian, E. (Eds.), 2016. Höhlen und Karst in Österreich. Oberösterreichisches Landesmuseum, Linz, $752 \mathrm{p}$.

Stock, G.M., Granger, D.E., Sasowsky, I.D., Anderson, R.S., Finkel, R.C., 2005a. Comparison of U-Th, paleomagnetism, and cosmogenic burial methods for dating caves: Implications for landscape evolution studies. Earth and Planetary Science Letters, 236, 388-403. https://doi.org/10.1016/j.eps1.2005.04.024

Stock, G.M., Anderson, R.S., Finkel, R.C., 2005b. Rates of erosion and topographic evolution of the Sierra Nevada, California, inferred from cosmogenic ${ }^{26} \mathrm{Al}$ and ${ }^{10} \mathrm{Be}$ concentrations. Earth Surface Processes and Landforms, 30, 985-1006. https://doi.org/10.1002/esp.1258

Szekely, B., 2003. The Eastern Alps in an envelope - an estimation on the "missing volume". Neues Jahrbuch für Geologie und Paläontologie, 230 (2/3), 257-275. https://doi.org/10.1127/njgpa/230/2003/257

Wagner, T., Fabel, D., Fiebig, M., Häuselmann, Ph., Sahy, D., Xu, S., Stüwe, K., 2010. Young uplift in the non-glaciated parts of the Eastern Alps. Earth and Planetary Science Letters, 295, 159-169. https://doi.org/10.1016/j.eps1.2010.03.034

Winkler-Hermaden, A., 1957. Geologisches Kräftespiel und Landformung. Springer, Wien, $822 \mathrm{p}$. https://doi.org/10.1007/978-3-7091-7881-2 